\title{
EL MITO DE PROMETEO Y EPIMETEO Y LAS FINALIDADES DEL CASTIGO
}

\author{
(Protágoras)* $^{*}$
}

\section{1. ¿Qué es un sofista?}

Muy temprano, cuando aún no amanece, el joven Hipócrates, hijo de Apolodoro y hermano de Fasón, llega a casa de Sócrates y, dirigiéndose al dormitorio del filósofo, le comunica que es portador de una gran noticia: Protágoras de Abdera está en Atenas y se aloja en la morada de Calias, el hijo de Hipónico. El visitante anuncia a Sócrates su deseo de conocer al célebre maestro y de beneficiarse con su enseñanza, por caro que esto pueda costarle. Espera que el filósofo lo recomiende con el abderitano, a fin de que éste acceda a lo que Hipócrates quiere pedirle. - ¿No convendría -inquiere después- que fuésemos a casa de Calias antes de que su huésped salga?... Sería anticiparnos -objeta Sócrates. Vayamos afuera y conversemos allí hasta que rompa el dfa.

Mientras pasean por el patio el moralista pregunta a Hipócrates qué espera recibir de Protágoras a cambio de lo que se propone darle. -Si fueras en busca de ese gran hombre que se llama como tú y le ofrecieses dinero por sus lecciones, ¿qué propósito te movería?... - Convertirme en médico -responde el joven. - $\mathrm{Y}$ al acudir a Protágoras, ¿lo harás para volverte un sofista, o te daría vergüenza presentarte como tal ante los ojos de los helenos?... - "Sí, por Zeus, Sócrates, me daría vergüenza, si en verdad he de expresar lo que pienso." " - Ya veo: lo que anhelas no es llegar a ejercer el oficio de Protágoras, sino mejorar tu educación...

Fiel a su costumbre de definir rigurosamente los términos, el hjio de Sofronisco pide a Hipócrates que juntos examinen cuál es el arte que Protágoras cultiva, y el segundo asevera que la profesión del abderitano es formar hombres elocuentes. - Lo que afirmas puede ser cierto — comenta Sócrates_; mas no basta, pues lo que debe preocuparnos es saber en qué materias hace el sofista elocuentes a quienes lo escuchan. Si el tocador de lira vuelve elocuentes a sus discípulos en lo que atañe al empleo de ese instrumento, ¿no habrá que decir, de modo paralelo, que el sofista vuelve elocuentes a los suyos en lo que sabe y les trasmite? Pero, ¿qué es en realidad lo que el sofista sabe y enseña?...

Como Hipócrates se declara incapaz de responder, Sócrates le advierte que corre un gran peligro, ya que está a punto de gastar su fortuna para ponerse en manos de un hombre a quien no conoce, y de cuya actividad profe-

* Capitulo de una obra en prensa.

1 Protagoras, $312 a$. 
sional no tiene la menor idea. Es como si, de hallarse enfermo, recurriese a un médico desconocido, que en vez de curarlo podría arruinar su salud.

"El sofista - sostiene Sócrates- es una especie de mercader, al por mayor o al menudeo, de las cosas de que se alimenta el alma." 2 _ ¿Cuáles son ellas? -interroga el joven. - Las doctrinas ${ }^{3}$ - contesta el filósofo, y añade que hay que tener cuidado con quienes las difunden, porque éstos, a fuerza de ponderar sus mercancías, acaban por engañarnos, como suelen hacerlo los que comercian con las necesarias para el cuerpo. Pues los últimos, sin importarles si sus víveres son buenos o malos, los alaban con exceso, a fin de venderlos pronto y obtener pingües ganancias. Algo parecido ocurre con los mercaderes que recorren las ciudades ofreciendo su ciencia a los que desean adquirirla y exaltan por igual todo lo que venden. Con ellos el riesgo es más grande que con los otros, pues lo que nutre al alma ha de escogerse con mayor cautela que las provisiones de boca.

Al ver que ha amanecido, Sócrates propone a su visitante que se dirijan a la mansión de Calias, donde se hospedan no sólo el ilustre sofista, sino Hipias de Elis, Pródico de Ceos y otros adeptos del retórico de Abdera.

\section{Protágoras habla de su profesión}

Al ser recibidos en casa de Calias, Sócrates y su amigo encuentran a Protágoras delante del pórtico, paseando en compañía de su anfitrión; de Paralos, hijo de Pericles, y de Carmides, hijo de Glaucón. Cerca estaban Jantipo, hijo también de Pericles; Filípides, hijo de Filomeles, y Antimeros de Merenda, dilecto discípulo del abderitano. Tras ellos caminaban muchos otros, en su mayor parte extranjeros, séquito habitual del sofista. Esta brillante comitiva moviase con gran respeto detrás de Protágoras, teniendo buen cuidado de no ponerse delante de él. Cuando el maestro giraba sobre sus pasos, los que le seguian colocábanse en círculo a derecha e izquierda hasta que él pasaba, a fin de situarse nuevamente a sus espaldas.

Al otro extremo del pórtico, sobre un sitial elevado, veíase a Hipias de Elis, y en torno suyo, sobre las gradas, hallábanse Erixímaco, hijo de Acumenos; Fedro de Mirrinusia; Andrón, hijo de Androtión, y varios coterráneos de aquél, que le hacían diversas preguntas sobre temas de física y astronomía.

Después de contemplar a esta pléyade de doctos personajes, Hipócrates y el hijo de Sofronisco se acercan a Protágoras, y el segundo dice al sofista:

- Protágoras, Hipócrates y yo hemos venido a verte.

El retórico inquiere si desean hablarle a solas o delante de los presentes. Sócrates le explica que su acompañante, a quien describe como hombre de

2 Ibid., $313 c$.

3 Hemos vertido la voz griega $\mu \alpha \dot{\theta} \theta \eta \mu \alpha$ por doctrina, y no por conocimiento, como lo hacen la mayoria de los traductores, porque sólo de las doctrinas, y no de los conocimientos, puede decirse con propiedad que son verdaderos o falsos. De las versiones del Protágoras que tuvimos a la vista, únicamente en la de W. R. M. Lamb (Loeb Classical Library), $\mu \alpha \dot{\theta} \eta \mu \alpha$ se traduce por doctrina. 
tan buen natural que por ningún otro de su edad es igualado, tiene la ambición de distinguirse en su patria y está persuadido de que, para lograrlo, las lecciones de Protágoras le resultarán imprescindibles. El sofista no disimula su interés en que la conversación que Sócrates acaba de iniciar sea escuchada por los que le rodean, y el hijo de Sofronisco, para halagar al abderitano, hace la sugerencia de que Hipias y Pródico se unan al grupo. Protágoras accede gustoso y, entre todos, traen sillas que colocan cerca de Hipias, donde había ya buen número de bancos. Una vez que los huéspedes de Calias se han sentado, el sofista pide a Sócrates que repita frente a los circunstantes lo que poco antes había empezado a decirle. El segundo declara que Hipócrates arde en deseos de recibir las lecciones del maestro de Abdera, y quiere saber qué clase de ventajas le reportará tal enseñanza.

Entonces Protágoras, volviéndose hacia Hipócrates, le dice: "-Querido joven, lo que ganarás con mis lecciones será que desde el día en que estés conmigo volverás a tu casa hecho un hombre mejor, y lo mismo ocurrirá al día siguiente. Y cada vez tus progresos serán más grandes." "

Sócrates observa que ello nada tiene de extraño, y que lo mismo sucedería si Hipócrates, en vez de estudiar con Protágoras, lo hiciese con un maestro de pintura, que también podría prometerle hacerlo siempre más hábil. No hay duda de que, gracias a su dedicación, el discípulo hará progresos cada día; pero parece conveniente que el maestro aclare qué clase de progresos serán éstos.

Protágoras responde que la pregunta le agrada, y que Hipócrates no correrá a su lado el riesgo que correría con otros maestros, que obligan a sus alumnos a estudiar materias que ni les interesan ni habrán de serles útiles, en tanto que con él Hipócrates aprenderá lo que realmente le importa, "la prudencia en el trato de los propios asuntos, que indica cómo puede uno administrar su casa de la mejor manera; y, respecto de los negocios públicos, en qué forma se vuelve uno máximamente capaz de intervenir, por medio de la acción y el discurso, en la vida del Estado". ${ }^{5}$

Estas palabras revelan el propósito de Protágoras: trasmitir a sus oyentes un saber eminentemente práctico, relacionado no sólo con el manejo de sus asuntos domésticos, sino con su intervención en los de la polis.

Pasando por alto la primera finalidad de la enseñanza del abderitano, Sócrates parece interesarse sólo por la segunda, y dice a Protágoras que, si ha entendido bien sus expresiones, el objetivo principal de su docencia es convertir a sus discípulos en buenos ciudadanos.

- Precisamente - contesta el sofista - eso es mi mayor orgullo.

- La polftica es un arte maravilloso, si es cierto que lo posees - comenta Sócrates-; mas no tengo empacho en confesarte lo que de ella pienso. Tú aseguras que la enseñas, pero yo he creído siempre que no depende de los hombres comunicarla a los demás. Voy a exponerte las razones que me inducen a pensar así. Juzgo, como todos los helenos, que los atenienses son muy sabios. Cuando se reúnen en sus asambleas y la ciudad tiene necesidad de

4. Protágoras, 318a-b.

5 Ibid., $318 e-319 a$. 
que se levante un edificio, se llama a los arquitectos para que den su dictamen; si se proyecta la construcción de un navío, convocamos a los versados en cuestiones náuticas, y lo mismo hacemos respecto de aquellas otras que por su misma naturaleza pueden ser enseñadas y aprendidas; y si alguno que no tiene conocimiento de ellas se mete a dar consejos, nadie lo escucha, por bueno, noble o adinerado que sea. Es más: todos se burlan de él, le silban o hacen que se le arroje del recinto. En cambio, cuando se delibera sobre problemas que conciernen a la administración del Estado, se oye indiferentemente a todo el mundo, ya se trate de un labrador, de un herrero, de un fabricante de calzado, de un comerciante o del capitán de una nave, sin tener en cuenta si es rico o pobre, noble o plebeyo, y ninguno les echa en cara que hablen de cosas que jamás han aprendido y por nadie son enseñadas, 10 cual es prueba evidente de que no son enseñables. Ello sucede no sólo a propósito de los asuntos de la polis, sino también en lo relativo a la conducción de los de índole privada. En estas materias no hay profesores, y los más competentes entre nuestros conciudadanos se consideran incapaces, en lo que a tales materias atañe, de comunicar su sabiduría a los demás. Pericles ha hecho que sus dos hijos aprendan todo lo que puede ser objeto de instrucción; pero en punto a capacidad política, ni él los alecciona, ni los envía a casa de ningún experto. Hay muchos otros ejemplos de hombres hábiles en el manejo de los asuntos públicos, pero ninguno de ellos ha logrado trasmitir su experiencia a sus propios hijos, ni tampoco a los ajenos. Todo ello - concluye Sócrates- me inclina a pensar que la virtud no puede ser enseñada; pero si tú, Protágoras, estás en condiciones de demostrar lo contrario, por favor, no nos escatimes tu saber. ${ }^{6}$

\section{Fábula de Prometeo y Epimeteo}

Después de escuchar los razonamientos del filósofo, Protágoras le pregunta si desea que él, como hombre viejo que se dirige a los más jóvenes, haga la demostración de la tesis opuesta por medio de un mito o de una argumentación en forma.

Los presentes exclaman que Protágoras debe elegir la manera de hacerlo. - Siendo así - contesta el sofista — juzgo que una fábula será más agradable:

"Hubo una vez un tiempo en que los dioses existían, mas no había criaturas mortales. Cuando, señalada por el destino, llegó para éstas la hora de nacer, las divinidades las modelaron en el interior de la Tierra, haciendo una mezcla de tierra y fuego, y de cuantas materias con el fuego y la tierra se combinan. Y, cuando estaban a punto de sacarlas a la luz, encargaron a Prometeo y Epimeteo ${ }^{7}$ que las dotaran, atribuyendo a cada una las facultades

6 $7 b i d$, $320 b-c$.

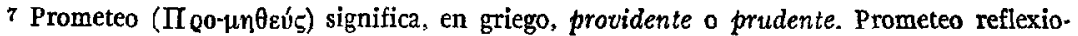

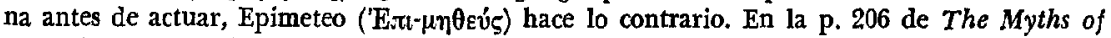
Plato (Los mitos platónicos), J. A. Stewart traduce Prometeo y Epimeteo por Forethougt y Afterthougt, o sea, para buscar un equivalente en castellano, por Piensaprimero y Piensadespues. 
convenientes. Epimeteo suplicó a Prometeo que le permitiese hacer él la distribución. —Cuando la haya hecho _dijo_ tú la examinarás." $s$

Epimeteo dotó a los animales con los atributos más disímiles, procurando al hacerlo que la repartición fuese justa, de manera que las ventajas concedidas a unos quedasen compensadas con los privilegios otorgados a otros. "Urdió todo ello teniendo cuidado de que ninguna especie fuera a extinguirse; y una vez que las proveyó de medios para evitar las destrucciones mutuas, ideó un recurso frente a las estaciones dispuestas por Zeus, vistiéndolos con espesas pelambres y duros carapachos, suficientes para protegerlos contra el invierno y capaces, también, de defenderlos de los calores, de suerte que, al ir a sus guaridas, les sirvieran de lecho propio y natural para cada uno." 9

Epimeteo, que no era muy prudente, repartió entre los animales todo lo que había que repartir, olvidándose por completo de los hombres. Próximo estaba el día en que los humanos debian aparecer sobre la Tierra, y Prometeo, que pronto se percató del descuido de Epimeteo, no sabla qué partido tomar. Pero al fin encontró un ingenioso expediente: sustrajo del taller de Hefesto y Atenea el fuego y los secretos de las artes, e hizo con ellos un presente al hombre. Cuando éste gozó de esa "porción divina", fue "el único de los vivientes" que rindió culto a los dioses y se puso a levantarles altares y estatuas; además, por su destreza, "rápidamente articuló sonidos y palabras"; encontró la forma de hacer casas y vestidos, y aprendió a procurarse los productos de la tierra. Provistos de tal modo, "en los comienzos los humanos vivian dispersos y no había ciudades; en consecuencia, eran diezmados por las fieras, debido a que, en todos los respectos, resultaban más débiles que ellas". Su habilidad manual era suficiente recurso en lo que atañe al alimento, "pero insuficiente para su lucha contra las bestias feroces, pues aún no tenían el arte cívico, del cual el de la guerra es una parte". 10 Trataban, pues, de reunirse y conservarse fundando ciudades; pero, al congregarse, "cometian incontables injusticias, por lo que, dispersándose de nuevo, perecían. Entonces Zeus, temeroso de que nuestra especie se extinguiese del todo, envio a Hermes para que llevara a los hombres el respeto mutuo y la justicia, a fin de que hubiese ordenamientos y lazos que estrecharan su amistad". ${ }^{11}$ Hermes preguntó a Zeus de qué modo daría a los hombres tales dones. - "Acaso he de repartirlos en la forma en que las artes lo han sido?... Pues éstas lo fueron así: uno solo, conocedor del arte médico, es suficiente para muchos que lo ignoran, y lo propio ocurre con los que ejercen otras profesiones. ¿Depositare

8 Protágoras, $320 \mathrm{~d}-\mathrm{c}$.

9 lbid., $321 a$.

10 lbid., $322 a \cdot b$.

11 Ibid., 322c. Refiriéndose a estos términos, Guthrie escribe: "Dikë es el sentimiento del dexecho o la justicia; aidōs una más complicada cualidad en que vagamente se combinan los sentimientos de vergiienza, pudor y respeto a los demás." W. K. C. Guthrie, A History of Greek Philosophy (Historia de la filosofia griega), tercer volumen, p. 66. En su Philosophischer Handkommentar zu den Dialogen Platos (Comentario filosofico-manual a los diálogos de Platón), Hermann Gauss vierte la segunda de las dos voces por "pudor" (Schamgefühl) y "conciencia" (Gewissen). A. E. Taylor, Plato. The Man and his Work, traduce $\delta i x \eta$ por sense of right y aibós por conscience (p. 243). 
también de esta manera en los hombres la justicia y el respeto mutuo, o he de repartirlos entre todos?" - "Entre todos _repuso Zeus-, que todos tengan su parte, pues las ciudades no llegarian a formarse si sólo unos cuantos participaran de aquéllos como de las otras artes. $\mathrm{E}$ instituye en mi nombre la ley de que, a quien no pueda ser partícipe del respeto recíproco y de la justicia, se le haga morir cual si fuese un cáncer de la ciudad." ${ }^{12}$

\section{Sobre el fundamento y las finalidades de la sanción penal}

Esta fábula, prosigue Protágoras, revela por qué "los atenienses, cuando se discurre acerca de la excelencia de un maestro o de cualquier artesano, piensan que hay que ir hacia pocos en busca de consejo, y en caso de que alguno, no siendo de estos pocos, se atreva a aconsejar, no lo soportan, como tú dices, Sócrates, y con toda razón, como afirmo yo. Mas cuando necesitan asesoramiento sobre la excelencia cívica, que debe ir totalmente de acuerdo con la justicia y la sensatez, aceptan el parecer de todo hombre, como si a todo hombre correspondiera participar de tal excelencia..." 13

$\mathrm{Si}$ alguien se jacta de ser un buen flautista o de descollar en cualquier otro arte que en realidad desconoce, todo el mundo se mofa de él, "y los suyos, acercándose, lo motejan de loco". ${ }^{14}$ Pero si el que es injusto confiesa serlo en presencia de muchos, los que respecto de las artes tenían por buen sentido decir la verdad, al hombre que pregona su injusticia lo juzgan insano, $\mathrm{y}$ aseguran que todos deben sostener que son justos, sea que lo fueren o no. Ciertamente con buen juicio, los atenienses admiten como consejero, en cuestiones relacionadas con los asuntos públicos, a cualquier ciudadano, porque están persuadidos de que todos los miembros de la polis participan de la justicia, virtud de la que creen que "no existe por naturaleza ni de modo espontáneo, sino que puede enseñarse y, con esfuerzo, ser adquirida". ${ }^{\text {t5 }}$ Quien no trata de adquirirla y cae en el vicio contrario, indefectiblemente provoca "los estallidos de ira, los castigos y las admoniciones". ${ }^{10} \mathrm{Si}$ la virtud no fuese algo que "con diligencia y estudio" podemos procurarnos, imposible sería entender por qué se sanciona a quien delinque. "Pues nadie, precisamente por estar dotado de razón, castiga a los que son injustos por el hecho de que obraron injustamente, a no ser que, cual bestia salvaje, se vengue sin ningún

12 Protágoras, 322d. Comentando el mito de Prometeo y Epimeteo, Adolf Menzel afirma que "Protágoras describió el desarrollo de la cultura humana como una línea ascendente. Hasta los años en que el sofista griego dialoga con Sócrates, generalmente se creía en la existencia de una edad de oro, colocada en los orígenes de la historia humana; el mismo Platón festejó esta tesis en alguno de sus diálogos" (Menzel, Calicles, traducción de Mario de la Cueva. Centro de Estudios Filosóficos de la Universidad Nacional Autónoma de México, 1964, p. 17). En un apéndice al capitulo iv de su Historia de la filosofía griega, vol. II, pp. 79-84, Guthrie incluye una serie de interesantes pasajes de autores griegos (Esquilo, Sofocles, Empédocles, Diódoro, Critias, etc.) "descriptivos del progreso humano".

13 Ibid., 322 d-e.

14 Ibid., $323 a$.

15 Ibid., $323 \mathrm{c}$.

16 Ibid., $323 e$. 
fundamento... El que trata de castigar con razón no se venga en vista de la injusticia pasada - pues no consideraría lo ya hecho como no ocurrido- sino en atención a lo porvenir, para que no cometa nuevamente injusticias ni este mismo ni otro alguno, al ver que aquél fue castigado; $y$, teniendo tal pensamiento, comprende que la virtud puede ser objeto de educación, ya que castiga con un propósito preventivo." 17 Quienes sancionan a los malos, ya en privado, ya en público, lo hacen con este fin, tanto los atenienses como todos los demás, pues están convencidos de que la virtud puede ser adquirida y enseñada. ${ }^{18}$

\section{Tras el mito, el razonamiento}

Protágoras se refiere después a la tesis socrática de que los hombres que han dado pruebas de la mayor excelencia civica se sienten incapaces de trasmitir ésta a sus hijos, lo mismo que a otros ciudadanos.

- Para responder a tu objeción —dice el sofista a Sócrates- no recurriré a una fábula; me valdré de un razonamiento. $\mathrm{Si}$, como lo he demostrado, la virtud puede enseñarse, ¿te parece creible que los grandes hombres se preocupen por instruir o hacer que se instruya a sus hijos en las artes que sin riesgo de castigo pueden ser ignoradas, y renuncien a que aprendan las cosas cuya ignorancia va ordinariamente seguida de la cárcel, del destierro, de la confiscación de bienes o incluso de la muerte?

"Comenzando desde su más tierna edad, hasta el último momento de sus vidas, los instruyen y amonestan. Tan pronto como uno de ellos comprende lo que se le dice, tanto la nodriza como la madre, y el pedagogo, y el mismo padre, luchan con empeño para que el niño llegue a ser como el mejor, enseñándole y explicándole; respecto de cada acto y cada palabra, que esto es justo y esto injusto; que una cosa es noble y otra vergonzosa; que ésta es santa y aquélla impía; que se ha de hacer esto y no hacer lo otro. Y si obedece

17 Protágoras, 324a-c. A. Menzel comenta asi el pasaje citado: "En las palabras de Protágoras encuentran una expresión magnifica la superación de la teoría de la pena como recompensa o retribución por el acto consumado, predominante en aquellos años, y la fundamentación del derecho a castigar en la idea de fin, pues la pena debe provocar temor $y$, al imponerse, ha de procurar el perfeccionamiento de la persona. El conocido apotegma de que se castiga 'non quia peccatum est, sed ne peccetur', que sirve de base al derecho penal aun en nuestros días, viene rodando desde los años en que vivió el sofista de Abdera." Menzel, obra y traducción citadas, p. 16. En relación con el mismo tópico, Taylor afirma que es fácil entender por qué los atenienses realmente pensaban que la virtud puede enseñarse, si reflexionamos en que no "corregían" ni "censuraban" a quienes tenían defectos físicos de los que no eran responsables. "Al hombre que es feo, pequeño o enfermizo no se le reprende ni se le corrige: se le tiene lástima. Pero los hombres son justamente reprendidos y castigados cuando delinquen, y el propósito es que la reprimenda o el castigo puedan ser una 'lección' para el delincuente o para otros, a fin de que no cometan delitos en lo futuro. La simple existencia de la justicia criminal es así una prueba de que la virtud puede ser objeto de aprendizaje." A. E. Taylor, Plato. The Man and his Work. Methuen, London, 1960, p. 244.

18 El punto es ampliamente discutido en la obra a que remite la nota anterior (cap. $\mathrm{x}, \boldsymbol{\Pi}$, pp. 24I-247). 
de buen grado, bien; pero si no, lo enderezan con amenazas y golpes, cual si fuese un trozo de madera torcido y doblado." 19

Es cierto que los hijos de padres buenos pueden llegar a ser malos; pero esto sólo prueba que aunque la virtud sea enseñable, no todos se hallan igualmente dotados para adquirirla, y lo mismo ocurre con cualquiera de las artes. Si supusiésemos que tocar la flauta fuese tan necesario para la vida de la polis como la excelencia cívica, "¿piensas acaso, Sócrates, que los hijos de los buenos flautistas, más que los de los malos, llegarian a ser buenos tocadores de flauta?' 20 Las capacidades y aptitudes son siempre variables, tanto en el campo de la política como en el de la técnica. Y cuando, respecto del primero, faltan del todo, al negado para adquirir y practicar las virtudes que hacen posible la convivencia se le da muerte, a fin de acatar esa divina ley que el mito de Prometeo menciona.

\section{6. ¿Hay una o muchas virtudes?}

Luego de escuchar el anterior discurso, Sócrates, dirigiéndose al sofista, le dice: - Ahora, Protágoras, sólo me falta que me contestes esto: "la virtud, en tu opinión, puede ser enseñada, y si yo me dejase convencer por alguno de los hombres, sería por ti; pero al estar tú hablando, algo me sorprendió; da, pues, satisfacción a mi espiritu. Afirmabas que Zeus envió a los hombres la justicia y el respeto mutuo y, después, a menudo sostienes que la justicia, la templanza, la santidad y todo lo demás, serían, en suma, una sola cosa: la virtud. Por tanto, explícame con precisión si en verdad la virtud es algo uno, de lo cual son partes la justicia, la templanza y la santidad, o si las que yo ahora mencionaba son todas nombres del mismo ser uno." 21

"Siendo una sola cosa la virtud -responde Protágoras-, aquello por lo que preguntas son sus partes."

-iAcaso -inquiere nuevamente Sócrates _ "son partes suyas como lo son las de la cara: boca, nariz, ojos y ofdos, o como las del oro, que no difieren unas de las otras ni entre sí ni respecto del todo, salvo en grandor y pequeñez?" 22

Las partes de la virtud -opina Protágoras- son como las de la cara (en relación con todo el rostro). -Pero -insiste Sócrates_ "ecómo participan los hombres de estas porciones de la virtud: unos de ésta, otros de aquélla, o es necesario que si alguien posee una, tenga todas las demás?" 23

A este planteamiento sigue una larga discusión, en uno de cuyos momentos Protágoras admite que las virtudes se parecen entre si, aunque hay una,

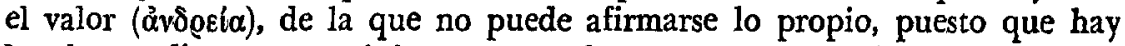
hombres valientes, pero injustos, y muchos otros que, siendo justos, no son

19 Ibid., $325 c-d$.

20 Ibid., $327 b$.

21 Ibid., 329 bc. Sobre la tesis socrática de la unidad de las virtudes, cf. A. E. Taylor, obra citada, cap. x, III, pp. 247-251.

22 Ibid., 399 d.

23 Ibid. 
valerosos. ${ }^{24}$ El examen de este tópico conduce a Sócrates a uno de los principios básicos de su filosofía: el de que la virtud es saber. ${ }^{25}$ Tal principio tiene dos corolarios: 1) no hay hombres malos, sólo hay ignorantes; 2) quien prefiere el vicio a la virtud es víctima de un error de cálculo. Además, si la virtud es saber, podrá ser enseñada. Esta es la verdadera convicción socrática, la piedra angular de su magisterio. La pregunta que el moralista formula al iniciar el diálogo con Protágoras obedece sólo al deseo de que el sofista hable de la índole y finalidades de su docencia. ${ }^{26}$

En relación con el tema central de esta obra, las doctrinas que Sócrates defiende en la última parte del coloquio pueden resumirse así: 1) sólo es en verdad justo quien conoce la esencia de la justicia; 2) tal conocimiento, para ser cabal, ha de referirse no únicamente al ser de dicha virtud, sino a las consecuencias que su ejercicio produce; 3) el hombre que prefiere la injusticia a la justicia yerra por partida doble: en lo que respecta a la esencia de lo justo y de lo injusto y en lo que atañe a los resultados o efectos del vicio y la virtud correspondientes. Estos son los temas que, después de la conclusión negativa del libro $\mathrm{x}$ de La República, serán prolijamente discutidos en los libros II a IV del mismo escrito. ${ }^{27}$

\section{Comentario}

I. Los conocedores de los diálogos, con muy pocas excepciones, ${ }^{28}$ consideran que, si atendemos al valor filosófico de las doctrinas que contiene, el Protágoras resulta inferior a la mayoría de los escritos del Filósofo de la Academia. En cambio, de modo unánime declaran que como obra artística es, si no la más bella, sí una de las producciones estéticamente mejor logradas, del pensador ateniense. Taylor, por ejemplo, escribe: "Si existe un diálogo que pueda disputar al Banquete la pretensión de ser el chef d'oeuvre de su autor, ese diálogo es el Protágoras, con su brillante y amplia semblanza del famoso maestro y sus alegres bocetos de los sofistas menores, Pródico e Hipias." ${ }^{29}$ Por su parte, Guthrie opina que "aunque el Protágoras no nos brindase ninguna lección filosófica", seguiría siendo, pese a ello, "una soberbia obra de arte literario". ${ }^{30} \mathrm{El}$ mismo helenista combate el aserto, defendido por nume-

24 Protágoras, $329 e$.

25 Cf. Taylor, obra y capitulo citados en la nota 21, secciones v y vi, pp. 257-262.

26 Ia virtud, como Sócrates la entiende, "no es asunto de tradiciones" sino un saber "que se rige por principios"; se trata, a no dudarlo, de un "conocimiento" y, por tanto, de algo que puede ser "enseñado". Taylor, op. cit., p. 246.

27 En el próximo capítulo nos referiremos al libro I de La República. Sobre las tesis expuestas en los libros II-IV del mismo diálogo pueden ser consultadas las siguientes obras: R. L. Nettleship, Lectures on The Republic of Plato. Macmillan \& Co. Ltd., Nueva York, 1964, capítulos I-VII; R. C. Cross y A. D. Woozley, Plato's Republic. A Philosophical Commentary, Macmillan, 1970, capitulos 3 y 4; N. R. Murphy, The Interpretation of PLato's Republic, Oxford, at the Clarendon Press, 1967, capitulos I-II.

28 De todas ellas, la principal, sin duda alguna, es la estimación del valor filosófico del Protágoras en el capítulo $x$ de la ya citada obra de Taylor.

29 Obra citada en la nota anterior, p. 235.

so Guthrie, tomo iv de la obra a que remite la nota 12, p. 215. 
rosos críticos del siglo xIx, de que el opúsculo de que estamos hablando es un trabajo de juventud, o acaso, como lo sostuvo von Arnim en 1914, el primero de los diálogos platónicos. Ritter pensaba lo mismo, no sólo por razones de orden lingüístico, sino porque, a semejanza de Wilamowitz, "se resistía a creer que Platón hubiese podido retratar a Sócrates en forma tan poco halagüeña después de su destino de mártir". ${ }^{31}$ Coincidiendo con Nestle en este punto, Guthrie juzga que el Protágoras es el último de los diálogos "socráticos", y esto porque, aun cuando va "más allá" que los otros del mismo grupo, mantiene la estricta "aquendidad" ("pure this-worldliness") del enfoque de Sócrates, "sin exhibir ninguna impronta de los intereses matemáticos, metafísicos y escatológicos que enlazan a Platón con los pitagóricos y que, como razonablemente se conjetura, fueron fomentados por la primera visita de aquél a la Italia meridional y a Sicilia". ${ }^{32}$

II. Al conversar con Hipócrates, poco antes de salir para la morada de Calias, Sócrates expone, con su habitual franqueza, la mala opinión que de los sofistas tiene. Dos son las principales causas de su menosprecio. La primera ha de buscarse en la costumbre, iniciada por Protágoras ${ }^{33}$ y seguida después por sus discípulos, de cobrar honorarios por la instrucción que impartían. No puede ser más cruel la frase de que se vale para caracterizar a los miembros de ese grupo: son mercaderes, "al por mayor y al menudeo, de las cosas de que se alimenta el alma". ${ }^{34}$ Sócrates pensaba —escribe Jenofonteque al recibir dinero por sus lecciones los sofistas vendían su libertad, puesto que se obligaban a tener tratos con cualquiera que pudiese pagarles el estipendio que exigfan. ${ }^{35}$ Semejante práctica era a los ojos del filósofo una especie de prostitución. ${ }^{36}$

31 Obra y tomo citados en la nota precedente, p. 213.

32 Obra y tomo citados, p. 214.

33 Refiriéndose a esta costumbre, Gomperz escribe: "El concepto que los griegos tenían de la vida fue siempre aristocrático. La actividad industrial gozaba entre ellos de un prestigio aun menor que entre otras naciones cuya economía se basaba también en la esclavitud. 'Los corintios son los que menos desprecian a los artesanos, y los lacedemonios son los que más los desprecian', nos dice Herodoto, preguntándose si los helenos no tomaron de los egipcios su menosprecio de las industrias. En Tebas había existido la ley de que nadie podia ser elegido para una función pública si no se había mantenido alejado durante diez años de toda actividad en el mercado, y tanto el propio Platón como Aristóteles créan oportuno excluir a artesanos y comerciantes del pleno goce de los derechos cívicos. Poquísimas ocupaciones lucrativas, entre ellas en primer lugar la de médico, eran consideradas como no directamente incompatibles con el prestigio social. Realizar trabajo intelectual en favor de otra persona que pagaba una remuneración, era una actividad que llevaba adherida una mácula especial. Se la consideraba como un rebajamiento, una servidumbre buscada voluntariamente. Cuando la profesión del redactor de discursos o del abogado hizo su primera aparición, fue perseguida no menos que la del sofista por la burla de los autores de comedias. Si alguien, como el orador Isócrates, se había dedicado durante un tiempo a aquella profesión, hacía luego todo lo posible para borrar todo vestigio de esta actividad, y cuando el mismo Isócrates se vio obligado a abrir una escuela de oradores, vertió, según se cuenta, lágrimas de vergüenza al recibir su primer honorario." Theodor Gomperz, Pensadores griegos, trad. de Carlos Guillermo Körner, Editorial Guarania, Asunción del Paraguay, tomo I, p. 466.

34 Protágoras, $313 \mathrm{c}$.

35 Memorabilia, I, 2, 6 y I, 6, 5 .

36 Ibid., I, 6, 13. 
Otra de las causas del desdén que le inspiraba la actividad de los sofistas, era la índole de su docencia. Recordemos el parangón que traza al departir con su joven visitante: más temibles que los que comercian con los alimentos del cuerpo son los vendedores de las cosas de que se alimenta el alma. Así como el mercader sin escrúpulos sólo se preocupa por salir de sus mercancías, estén o no en buen estado, al que pone precio a sus doctrinas, sean o no verdaderas, no le interesa la salud moral de sus oyentes, sino hacerlos aptos para vencer, por cualquier medio, en las controversias judiciales o en las asambleas políticas. Lo decisivo, para quienes se vanaglorian de trasmitir tal destreza, no es la intrínseca bondad de las causas, sino la aptitud para hacerlas triunfar, aun cuando sean injustas. Esto se aplica también a quienes discuten sobre cualquier tema, pues "toda discusión es una batalla verbal en la que tiene que haber un vencedor y un vencido", ${ }^{37}$ y no, como lo afirmaba Sócrates, la búsqueda en común de un saber auténtico.

III. La respuesta que da el abderitano, cuando se le pregunta qué ventajas puede esperar Hipócrates de las lecciones que anhela recibir, claramente revela los objetivos de la enseñanza protagórica. Hipócrates no tendrá que estudiar materias que ni le interesan ni habrán de serle útiles, sino lo que realmente le importa: "la prudencia en el manejo de los propios negocios, que indica cómo puede uno administrar su casa de la mejor manera; $y$, respecto de los asuntos públicos, en qué forma se vuelve uno máximamente capaz de intervenir, por medio de la acción y el discurso, en la vida del Estado." 38 Trátase, pues, de un magisterio dirigido hacia el logro de finalidades utilitarias, así en la vida privada como en la esfera de la actividad política.

Protágoras y, con él, sus adeptos, estaban convencidos de que dentro de un régimen en que, como en actitud crítica decía Sócrates, lo mismo se escucha en las asambleas al pobre que al rico, al ignorante que al docto, al noble que al plebeyo, la oportunidad de ser partes en la discusión de los problemas comunes de ningún modo implica que los ciudadanos tengan talentos iguales ni parejas posibilidades de buen éxito. Tanto en los debates políticos como en cualquiera otro tipo de polémica, la victoria corresponde siempre al más diestro en el arte oratorio. En tales lides no se lucha con la espada, sino con la palabra, y los sofistas son, precisamente, los supremos maestros de esta esgrima verbal. Si respecto de cualquier tópico podemos en todo caso servirnos, como pretendía el abderitano, "de dos argumentos contrarios", habrá que reconocer que éstos no son nunca ni correctos ni falaces, sino fuertes o débiles, convincentes o no convincentes. ${ }^{39}$

Cuando Sócrates pregunta a Protágoras si el objetivo principal de su enseñanza es formar buenos ciudadanos, el sofista contesta que en ello cifra su mayor orgullo.40 Mas no hay duda de que lo que el retórico entiende por "buen ciudadano" de ningún modo coincide con lo que entiende Sócrates. "Buenos ciudadanos" son en realidad, para Protágoras, no los mejores en el

37 Cf. Guthrie, tomo In de la obra citada, pp. 24 y 51.

38 Protdgoras, $319 a$.

38 Cf. Gomperz, obra y traducción citadas, cap. vi, pp. 513 ss.

40 Protágoras, $319 a$. 
sentido socrático, sino "los más hábiles", es decir, los más duchos en el arte de imponer sus propias opiniones y, por ende, sus intereses. Los criterios de medida resultan, pues, muy diversos. Uno, el de Protágoras, es el logro de ventajas personales; otro, el de Sócrates, la subordinación de la conducta a principios que en ocasiones exigen que el individuo sacrifique sus impulsos egoístas en aras del bien común.

IV. Para responder a la objeción socrática de que la sabiduría política no puede ser objeto de enseñanza, Protágoras se sirve, como hemos visto, de vn mito y un razonamiento. En el catálogo de sus obras figura una cuyo título era Sobre el orden originario de las cosas. ${ }^{41}$ Se ha conjeturado que Ia fábula que Platón pone en boca del abderitano es, en lo esencial, una reproducción de puntos de vista del famoso retórico, expuestos, muy probablemente, en el mencionado escrito. ${ }^{42}$ Semejante parecer no es compartido por quienes, como J. A. Stewart, opinan que el de Prometeo y Epimeteo no es sólo una creación del filósofo de la Academia, sino el más bello de los mitos platónicos ${ }_{7}^{43}$

Las palabras iniciales del relato: "Hubo una vez un tiempo en que los dioses existian, mas no había criaturas mortales", deben tomarse, a juicio de los críticos, como un simple ornato literario, pues Platón sabía muy bien que en materia religiosa el abderitano se declaraba agnóstico. Así lo indican estas palabras: "Respecto de los dioses no tengo manera de averiguar si existen o no existen. En efecto, muchas cosas impiden saberlo: la oscuridad del asunto y la brevedad de la vida humana." ${ }^{4}$ Como Protágoras se jacta de que la finalidad de su labor es preparar a los ciudadanos para que intervengan con eficacia en el examen y solución de los asuntos públicos, lo que lógicamente supone que el arte de la política es enseñable, en su mito se niega que la capacidad para adquirir tal saber sea innata en el hombre.45 Por ello es necesario adquirirla, y su trasmisión exige, por una parte, la obra educativa del maestro y, por otra, la dedicación y el esfuerzo del discípulo. Esta idea y la que sirve de base al argumento de Sócrates no son incompatibles, pues si bien es cierto que en las asambleas politicas de Atenas se escucha a todo el mundo (sea pobre o rico, ignorante o instruido), ya que así lo demanda el principio fundamental de la democracia, este principio no supone que la igualdad de oportunidades de intervención en los debates demuestre que todos los ciudadanos tengan igual destreza ni las mismas posibilidades de triunfo. Pues, si las tuviesen, ninguna necesidad habria de prepararlos para esas luchas, ni, por ende, harían falta maestros para ello.

A diferencia de la virtud cívica, la aptitud técnica es congénita, pues, según el mito, Prometeo la concedió a los humanos desde que éstos vieron la

41 En el capitulo $\mathrm{Ix}, 55$, de Vidas de los filósofos ilustres, Diógenes Laercio incluye una lista de las obras atribuidas a Protágoras.

42 Cf. Guthrie, tomo uI de la obra citada, p. 63.

$43 \mathrm{~J}$. A. Stewart, The Myths of Plato, pp. 212 ss.

44 Diogenes Laercio, Vidas, Ix, 51-52. H. Diels, Die Fragmente der Vorsokratiker, II, 265, Protagoras, Fr. IV.

45 Protígoras, $323 \mathrm{c}$. 
luz.48 Apenas les fue otorgada esta "porción divina" empezaron a rendir culto a los dioses y "les levantaron altares y estatuas".

Al referirse a los inicios de la existencia humana, Protágoras distingue claramente dos etapas. Durante la primera, anterior a la formación de las comunidades políticas, los dones que Prometeo brindó a los hombres resultaban insuficientes, ya que, si bien los humanos pudieron conocer, gracias a tales dádivas, el fuego y los secretos de las artes, este saber técnico los colocaba en situación de inferioridad frente a las bestias feroces, que en todo caso

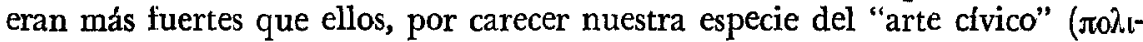

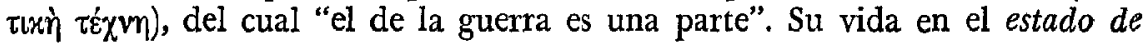
naturaleza, entendiendo por tal la situación que precedió a su convivencia en el seno de la polis, ponía en tal peligro al linaje humano, que Zeus, "temeroso de que nuestra especie se extinguiese del todo, envió a Hermes para que lle-

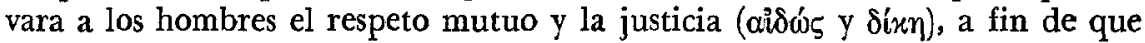
hubiese ordenamientos y lazos que estrecharan su amistad". Cuando Hermes preguntó a Zeus si debía depositar en los hombres la justicia y el respeto mutuo en la forma en que las artes fueron distribuidas, el padre de los dioses respondió: Debes repartirlos entre todos; "que todos tengan su parte, pues las ciudades no llegarían a formarse si sólo unos cuantos participaran de aquéllos como de las artes. $E$ instituye en mi nombre la ley de que, a quien no pueda ser partícipe del respeto recíproco y de la justicia, se le haga morir cual si fuese un cáncer de la ciudad".

¿Cómo hay que entender las palabras aỉós y $\delta \dot{x} x \eta$, de que Protágoras se sirve en su mito? Por lo que toca a la primera, juzgo que se refiere, como diríamos hoy empleando una expresión hartmanniana, ${ }^{47}$, al sentido o sentimiento de la justicia, es decir, a la aptitud, a todos otorgada, de intuir la esencia del mencionado valor, así como a la necesidad de fundar en él el orden legal de la polis. Dicha aptitud que, según la fábula, hizo posible el tránsito del primitivo estado de lucha y desorden a la vida politica, no garantiza, sin embargo, de acuerdo con esta exégesis, la total eficacia de aquel valor, porque los favorecidos con la dádiva que Prometeo olvidó brindarles tienen no sólo la capacidad de realizar la justicia a través de la formulación y el cumplimiento de los vópol, sino también (sea por incurable perversidad, sea por ignorancia), la de violar éstos, haciéndose así acreedores a los castigos que las leyes imponen. Aun cuando lo último no se diga en el mito, no hay duda de que está implícito, como lo prueba la teoría sobre el fundamento de la sanción penal, que Platón pone en labios del abderitano en el discurso que éste hace inmediatamente después, deseoso de explicar el sentido de su fábula.

En cuanto al otro término, que hemos traducido por respeto mutuo, lo que el retórico de Abdera quiere expresar es que, además del sentido o sentimiento de lo justo o, como consecuencia suya, los que pasan del estado natural a la vida política no ven ya a los demás como enemigos que pueden convertirlos en víctimas de sus violencias - cual ocurría en la etapa precedentesino como conciudadanos a quienes mueve el mismo anhelo de paz y de con-

46 Ibid., $321 c-d$.

47 Cf. N. Hartmann, Ethik, v, cap. 14. 
cordia. El respeto mutuo, como reconocimiento, por parte de cada miembro de la polis, de la dignidad ciudadana de los demás, implica, asimismo, que todos los joגíta tienen el deber de contribuir, hasta donde sus diversas aptitudes lo permitan, a la estructuración y mantenimiento del orden legal del Estado. Las normas que integran este orden no se fundan en la naturaleza; derivan del consenso mayoritario de quienes, después de establecerlas, quedan obligados a cumplirlas. Protágoras no es iusnaturalista; ${ }^{43}$ los vóno tienen su fuente en la libre voluntad de los súbditos. Para éstos, como expresamente lo afirma el retórico de Abdera, la justicia "no existe por naturaleza ni de modo espontáneo, sino que puede enseñarse y, con esfuerzo, ser adquirida" (323c). Estas palabras revelan, a nuestro entender, el propósito del mito de Prometeo y Epimeteo. Lo que Protágoras se propone es la justificación filo.

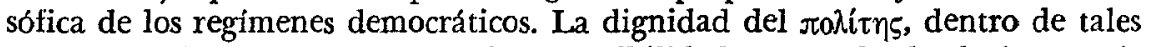
regímenes, depende, ante todo, de la posibilidad que se le da de intervenir en la creación del orden jurídico. El sentido o sentimiento de la justicia es lo que condiciona tal posibilidad. No se trata, empero, de una intuición cabal ni infalible de lo justo, sino de una aptitud cuyo mayor o menor perfeccionamiento se alcanza por obra de la educación. ${ }^{49}$ Recurriendo otra vez a giros hartmannianos ${ }^{50}$ podría decirse que Protágoras no sólo admite que hay casos de "estrechez o angostura" del sentido de la justicia, sino otros también de total "ceguera" para tal valor. Esto último explica las palabras que pone en labios de Zeus: " $E$ instituye en mi nombre la ley de que, a quien no pueda ser partícipe del respeto recíproco y de la justicia, se le haga morir cual si fuese un cáncer de la ciudad." 51

V. Examinemos ahora el pasaje en que el abderitano expone sus ideas sobre las finalidades de la sanción penal: "Nadie, precisamente por estar dotado de razón, castiga a los que son injustos por el hecho de que obraron injustamente, a no ser que, cual bestia salvaje, se vengue sin ningún fundamento. Pero el que trata de castigar con razón no se venga en vista de la injusticia pasada - pues no consideraría lo ya hecho como no ocurrido- sino en atención a lo porvenir, para que no cometa nuevamente injusticias ni este mismo ni otro alguno, al ver que aquél fue castigado; $y$, teniendo tal pensamiento, comprende que la virtud puede ser objeto de educación, ya que castiga con un propósito preventivo" (324a-c).

Del paso anterior se desprende:

1) Que la imposición de una pena no debe ser considerada como un acto de venganza.

2) Que debe tener, por el contrario, un fundamento racional.

3) Que la "razón" por la cual se castiga no ha de buscarse "en la injusticia pasada", pues "nadie consideraría lo ya hecho como no ocurrido". p. 71.

48 Cf. Guthrie, obra citada, rv, p. 217, y Ernest Barker, Greek Political Theory, 1970 ,

40 Protágoras, 324a- $\epsilon$.

so Cf. N. Hartmann, obra citada, v, cap. $16 e$.

51 Protágoras, $322 d$. 
4) Que el que castiga con razón lo hace atendiendo a lo porvenir (no a un hecho pretérito).

5) Que la pena se impone no sólo con el propósito de que el delincuente no reincida, sino a fin de que los demás, ante el espectáculo de la punición, se abstengan de delinquir.

6) Que la finalidad esencial de las sanciones penales es la prevención de futuros delitos.

Si nos atenemos a las palabras que Platón atribuye a Protágoras, podremos percatarnos de que en la doctrina protagórica sobre las finalidades de la pena no existe ninguna referencia a la idea retributiva, ya que, de acuerdo con aquellas palabras, no se sanciona al delincuente porque delinquió, sino para que no yuelva a delinquir.

En el mismo pasaje se sugiere, en cambio, que lo que con la imposición del castigo se busca es que el autor del hecho punible se arrepienta de su falta y salga "del error" en que incurrió al violar la ley.

¿Qué juicio debemos formarnos de una tesis a la que autores como Adolfo Menzel ${ }^{52}$ tributan tan cálidos elogios, por considerar que el abderitano "superó" la concepción "retributiva" de la pena?

Que el castigo no ha de tener el sentido de un acto de venganza sino un fundamento racional es evidente; pero el aserto de que "el que castiga con razón" no lo hace "en vista de la injusticia pasada" sino en atención a lo porvenir, no puede, a nuestro juicio, ser más desafortunado. Si ello fuese cierto resultaria imposible entender, primero, por qué se impone un sufrimiento al autor del delito (o, como Platón lo expresa) de la injusticia pasada; y, después, cómo pueda justificarse la afirmación de que se castiga al delincuente no por lo que hizo, sino por lo que aún no ha hecho, pero se teme que haga.

Recordemos el parecer de un destacado penalista contemporáneo: "Quien dice 'sanción' dice 'reacción', 'retribución', 'castigo' y, por tanto, expresa una idea que se orienta hacia el pasado, hacia algo que ocurrió, hacia la violación ya consumada de una norma, hacia la lesión de un bien protegido, no hacia algo que ha de producirse, como si la sanción se predispusiese para evitar la futura realización de un hecho lesivo." 53

Se ignora si la doctrina penal atribuida a Protágoras en el diálogo que lleva su nombre es realmente del sofista, o, como Apelt lo sostiene, ${ }^{54}$ se trata de una tesis platónica. Que Apelt está en lo justo nos parece indudable, no sólo porque la susodicha doctrina concuerda en lo esencial con las ideas que acerca de la pena expone el filósofo en varios de sus escritos, sino, sobre todo, porque en Las leyes repite textualmente las palabras de que, al tratar el mismo argumento, se sirve en el Protágoras. ${ }^{35}$

52 Cf. A Menzel, Calicles, trad. Mario de la Cueva p. 16.

53 Giuseppe Bettiol, Diritto Penale, Padova, Casa Editrice Dott. Antonio Milani, Sesta Edizione, 1966, p. 622.

54 Cf. Otto Apelt, "Platons Straftheorie", en Platonische Aufsätze (Ensayos platónicos), Arno Press, Nueva York, 1976, pp. 189 ss.

55 Leyes, 934a-b. 
Habrá, pues, que considerar el pasaje transcrito no en forma aislada, sino en conexión con los restantes aspectos de la concepción platónica del delito y de la pena.

Punto de partida de ésta son las siguientes tesis socráticas:

$1^{\text {a) }}$ Nadie es voluntariamente injusto.

$\left.2^{a}\right)$ Sufrir una injusticia es preferible a cometerla.

$\left.3^{a}\right)$ Quien comete iniquidades "es desdichado en todo caso, pero aún más desdichado si no se le sanciona ni es objeto de retribución por sus actos de injusticia, aunque menos desdichado si se le inflige una pena". ${ }^{36}$

De estas ideas trataremos in extenso en el capitulo siguiente, así que, por ahora, nos limitaremos a resumir las conclusiones a que Sócrates llega en el Gorgias al discutir con Polo:

1) Ser castigado no es obrar, sino padecer.

2) El sufrimiento que la pena ocasiona a quien delinque es impuesto por el funcionario a quien se encomienda la tarea de castigar.

3) El que castiga con razón castiga con justicia, y el que recibe el castigo sufre una acción justa.

4) Lo que padece el castigado es bueno por su utilidad, ya que, gracias al castigo, puede aquél liberarse del mal que había en su alma.

5) Así como al enfermo se le conduce a casa del médico para que sea aten. dido, a los que se abandonan a la injusticia y el libertinaje hay que llevarlos ante el juez, para que se les aplique la sanción que merecen.

6) Si pensamos en dos enfermos, para inquirir cuál es más desdichado, aquel a quien se atiende para curarle y aquel a quien no se cura y sigue padeciendo, al segundo lo tendremos por más infeliz. Lo propio ocurre en el caso de la injusticia: el que por ella es castigado se ve libre del más grande de lôs vicios, que es la maldad, y el dolor que sufre lo beneficia, pues el castigo es la medicina del alma. ${ }^{57}$

El problema más arduo de los que plantean a Platón los principios socráticos que arriba enumeramos y de cuya verdad el filósofo de la Academia estaba convencido, deriva del aserto de que nadie es voluntariamente injusto

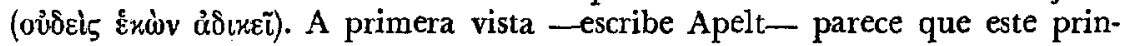
cipio hace imposible hablar de la pena. Si lo entendemos en su sentido literal excluye toda responsabilidad y con ella la justificación del castigo, "pues lo que hago sin querer no puede imputárseme como culpa". ${ }^{53}$ Pero sus distinciones psicológicas ofrecen a Platón los medios para establecer y caracterizar con gran sutileza las gradaciones que nuestro juicio formula acerca de la injusticia y del delito, en relación con las intenciones, la voluntariedad, etc. $\mathrm{Si}$ leemos sus ideas sobre el homicidio (Leyes, 865a), "encontraremos en ellas un clímax de la responsabilidad, con una clara distinción entre dolus y culpa". Así que, aun cuando el principio de la involuntariedad del entuerto "parezca cerrar todo camino a la pena, una consideración más cuidadosa revela que en lo fundamental es compatible con las concepciones criminalísticas, y

58 Gorgias, $472 e$.

57 Ibid., $478 d$.

58 Apelt, ensayo citado en la nota 54, p. 191. 
tiene sólo la peculiaridad de que, en lo que a las finalidades del castigo atañe, Platón relega a un segundo plano todos los demás puntos, para colocar en el primero las ideas de la enmienda y el progresivo aprendizaje. Como el acto violatorio de la ley es consecuencia de una antinatural falta de libertad del entendimiento, es decir, de una enorme limitación del dominio que a éste corresponde, el daño que el delito produce sólo puede ser subsanado si se ayuda a que el entendimiento recupere su imperio y total libertad. La instrucción y la mejoría que engendra es, pues, el fin propio y más noble de la actividad punitiva. Con él se contribuye a realizar al mismo tiempo la tarea fundamental del Estado, que consiste en hacer virtuosos a los hombres". 59

Según la concepción platónica, la pena es el sufrimiento con que la ley retribuye el mal causado por el delito. El hecho delictuoso no sólo daña a la víctima del entuerto; también causa un daño al alma del delincuente. Este daño es el que el dolor producido por la punición, obrando a un tiempo como medio educativo y como recurso terapéutico, tiende a corregir. Considerada no en lo que tiene de aflictiva, sino en sus efectos saludables, la pena resulta, moralmente hablando, un bien para quien la sufre. ${ }^{60}$

Aun cuando la forma en que la teoría de la prevención es presentada en el Protágoras y en los renglones de Las leyes que la reproducen parece excluir la idea de la retribución, nosotros creemos que lo que en otros escritos $y$, especialmente en el Gorgias, Platón expone acerca de los delitos y las penas, demuestra dos cosas: una, que si bien la teoría del castigo como medicina del alma subraya de manera exagerada la importancia de los efectos preventivos y ejemplares de la sanción penal, ello de ningún modo prueba que el autor de La República desconozca la naturaleza retributiva de tal sanción; otra, que numerosos textos de Las leyes y, sobre todo, el del Gorgias que hace pocos citamos, corroboran plenamente nuestro aserto. Acabamos de referirnos al pasaje que dice: "Quien comete iniquidades es desdichado en todo caso, pero aún más desdichado si no se le sanciona ni es objeto de retribución por sus actos de injusticia, aunque menos desdichado si se le inflige una pena" (472a).

No es nuestro propósito negar, por supuesto, que la pena tiene una eficiencia preventiva, tanto especial como general; ${ }^{61}$ lo que negamos es que se castigue no en vista del pasado (para retribuir el mal del delito), sino exclusivamente en atención a lo porvenir, "para que el delincuente no reincida y sirva de ejemplo a los demás su castigo".

"La prevención especial -escribe Bettiol- es uno de los objetivos de la pena, pero ésta, para no perder su naturaleza ética, debe ser reafirmación de la norma violada, debe ser retribución, pero retribución que en el caso concreto no olvide la personalidad moral del individuo y deje abierta la posi-

59 Ensayo a que remite la nota 54, p. 193.

60 Apelt, obra y ensayo citados, p. 194.

61 Sobre los conceptos de prevención general y prevención especial, cf. Bettiol, obra y edición citadas, p. 652 . 
bilidad, por la forma de su individualización y ejecución, de la enmienda del culpable." 62

VI. El punto más controvertido, en relación con la filosofía protagórica, deriva del aparente conflicto entre la doctrina epistemológica del sofista y la tesis que, a propósito de su obra educativa, Platón pone en labios del famoso retórico.

En el diálogo intitulado Teeteto, el filósofo de la Academia discute con gran prolijidad la sentencia del abderitano: "El hombre es la medida de todas las cosas, del ser de las que son y del no ser de las que no son." " ${ }^{33}$ ¿A qué se refiere, en esta frase, la palabra "hombre"? ( 0 ơv $\left(0 \omega \omega \pi 0_{5}\right)$ ): ca cada sujeto particular o a la especie humana? ${ }^{84}$ Platón, tomando como base el aspecto epistemológico de la doctrina, da a la tesis un sentido individualista y subjetivista. Para Protágoras - afírma Sócrates en el mencionado coloquio- cada cosa "es para mí como a mi me parece, y para ti como a ti te parece". Lo que aquél quiere decir - prosigue el hijo de Sofronisco - es, por ejemplo, que "cuando sopla un mismo viento, uno de nosotros siente frio y otro no lo siente, éste poco y aquél mucho". ${ }^{65}$ Surge entonces la pregunta: el viento, tomado en sí mismo, ¿es frío o no es frío?... ¿ $\mathrm{O}$ tendremos fe en Protágoras, que quiere que sea frío para el que así lo siente, y no lo sea para quien lo juzga cálido?... En consonancia con la primera interpretación de la sentencia protagórica -explica Cornford- "ninguno de los dos sujetos a que el ejemplo se refiere tiene fundamento para pretender que el otro está en un error. Cada uno de nosotros es là única medida, el único criterio o juez de la existencia o realidad, para él, de lo que percibe". ${ }^{66}$ "Caliente" y "frío" son dos propiedades que pueden coexistir en el mismo objeto físico. Yo percibo una de ellas; tú percibes la otra. "El viento es frío para mi" significa que el frío es la propiedad que me aparece o me afecta, aun cuando no sea la que te afecta o te aparece a ti. Decir simplemente que "el viento es frío" podría naturalmente entenderse "en el sentido de que esta frase implica que el viento no es cálido. Pero de hecho es ambas cosas a un tiempo; por ello añadimos 'para mi', a fin de expresar que yo tengo conciencia de tal propiedad, aunque tú tengas conciencia de la otra"..87 Pero cabe una segunda interpretación: el viento no es, en sí mismo, ni caliente ni frío. No tiene ninguna de las propiedades que cada uno de los sujetos percibe, ni es, en sí mismo, perceptible; es "algo que existe fuera de nosotros" y origina mi sensación de frío y tu sensación contraria. Lo fró y lo cálido no existen de modo independiente en el objeto, y sólo adquieren existencia cuando el acto perceptivo se produce. Cornford juzga

62 Bettiol, op. cit., p. 657 .

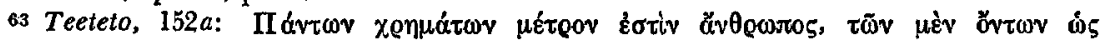

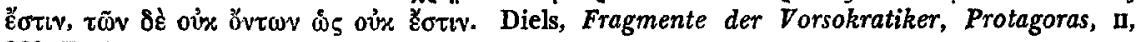
263, Fr. I.

64 A diferencia de casi todos los comentaristas, Gomperz sostiene que al hablar del hombre, Protágoras quería referirse no a cada individuo, sino, genéricamente, a la especie humana. Cf. obra y traducción citadas, tomo I, cap. VI, pp. 502 ss.

65 Teeteto, $152 a$.

60 Francis Macdonald Cornford, Plato's Theory of Knowledge, The Liberal Arts Press, Nueva York, 1957, p. 33 .

o7 Id. 
probable que Protágoras haya adoptado la primera de las dos interpretaciones: el viento es, a un tiempo, cálido y frío. Esta exégesis, comenta el mismo autor, coincide con Ia doctrina de Anaxágoras, quien sostenía que cualidades opuestas pueden darse en las cosas fuera de nosotros, y que la percepción lo es de los contrarios. A propósito de este punto, Cornford cita el siguiente pasaje de Sexto: "Protágoras asevera que la materia contiene los fundamentos subyacentes de todas las apariencias, de tal suerte que en ella, independientemente considerada, pueden existir todas las cosas que nos aparecen. Los hombres aprehenden objetos distintos en diversos momentos de acuerdo con sus variables condiciones. El que se halla en un estado normal aprehende en la materia lo que puede aparecer a una persona normal; el que se halla en un estado anormal aprehende lo que puede aparecer a un sujeto anormal. Lo mismo se aplica a diversas épocas de la vida, a los estados de sueño o de vigilia y a toda especie de condición. Así que, según Protágoras, el hombre prueba que es el criterio de todo lo existente: todo lo que le aparece existe también; lo que no aparece a ningún hombre no existe en absoluto." 68

Cuando cita a Sexto, para apoyar la primera interpretación de la sentencia de Protágoras -escribe Guthrie-Cornford omite la frase anterior al párrafo por él transcrito, en la que Sexto atribuye al abderitano la doctrina de que la materia está en constante flujo ( mación pertenece a la "enseñanza secreta" de que se habla en el Teeteto,70 y Sexto resulta ser "un testigo no fidedigno" de las ideas genuinamente protagóricas "cuando trata de ir más allá de la sentencia del sofista y de sus obvias implicaciones"."71

El resultado a que Guthrie llega, y que nosotros aceptamos, es que el retórico de Abdera defendió "un subjetivismo extremo de acuerdo con el cual no hay ninguna realidad detrás e independientemente de las apariencias, ni diferencia alguna entre aparecer y ser, por lo que cada uno de nosotros es juez idóneo de sus propias impresiones. Lo que a mí me aparece es para mí, y ningún hombre puede decir a otro que está equivocado. Si lo que yo siento cálido tú lo sientes frío, no cabe argumentar sobre ello: es cálido para mí y frio para ti". ${ }^{\prime 2}$

68 Cita de Cornford en la p. 35 de la obra a que remite la nota 66.

69 Guthrie, obra citada, tomo III, p. 185.

70 Teeteto, 152c-153d. Comentando estos pasajes, Cornford escribe: "Platón introduce en seguida otro elemento, requerido por su tema de la percepción sensorial. Tal elemento procede de Heráclito: 'Todas las cosas están en movimiento.' La sugestión de que Protágoras enseñó esto a sus 'discípulos' como 'doctrina secreta' no puede engañar a nadie. Protágoras no tenía escuela; cualquiera podía escuchar sus exposiciones y leer sus libros. Platón está insinuando que la doctrina del flujo universal realmente deriva de otra fuente, y procede a atribuirla a Homero y a todos los filósofos, con excepción de Parménides. No hay aquí más fundamento para inferix que Protágoras exa un heraclitano que para inferir que Homero también lo fuese. La intención de Platón es aceptar la doctrina de que todos los objetos sensibles cambian de modo incesante - principio fundamental de su propia filosofía. Pero para Platón esos objetos sensibles no son 'todas las cosas'. Más tarde sostendrá que el aserto irrestricto de que 'todas las cosas están siempre cambiando' hace del conocimiento algo imposible." Cornford, op. cit., p. 36.

71 Guthrie, obra citada, III, pp. 185 y 186 .

72 Obra y tomo citados en la nota anterior, p. 186. 
Este relativismo fue extendido por Protágoras al terreno ético. "Nuestra información - sigue diciendo Guthrie - se refiere únicamente a los Estados, ${ }^{73}$ pero es claro que si un hombre sinceramente piensa que robar es bueno, entonces para él, mientras siga pensándolo así, tal acto es bueno." 74 Pero de la misma manera que interesa al médico cambiar con sus drogas el mundo del enfermo, para que lo que le parece y es para él amargo le parezca y sea dulce para él, a la mayoría o a sus representantes, para quienes robar parece y es malo a un tiempo, "les interesa actuar por medio de la persuasión sobre el que cree lo contrario, hasta que su punto de vista - es decir, lo que para él es verdadero- cambie". ${ }^{75}$

Confirma plenamente la anterior exégesis el testimonio de Aristóteles en su Metafisica: "Protágoras afirmó que el hombre es medida de todas las cosas, que es como decir que lo que opina cada uno es la verdad; pues, si es así, resulta que la misma cosa es y no es, y es mala y es buena, y así lo demás que se dice en los juicios contradictorios, ya que muchas veces a unos les parece que una cosa determinada es hermosa y a otros lo contrario, y la medida es lo que aparece a cada uno." 76

Por otra parte, resultaría difícilmente explicable que Protágoras hubiese sido relativista en teoría del conocimiento y objetivista en el plano axiológico. En cuanto al problema que plantean las doctrinas que Platón le atribuye en el diálogo que estamos comentando, la solución se encuentra ya en el mismo escrito: todas las opiniones son igualmente defendibles, mas no todas tienen igual valor para la sociedad o el individuo. Aun cuando, como observa Guthrie, la conclusión lógica del subjetivismo protagórico sea la anarquía en lo moral y en lo político, tal resultado jamás fue admitido por Protágoras, quien creyó poder eludirlo al reemplazar el criterio epistemológico de verdad y falsedad por el puramente pragmático que ofrece la distinción entre lo mejor y lo peor, lo conveniente y lo inconveniente. "Las apariencias del momento son así subordinadas a un punto de vista superior: el fin o propósito de la naturaleza humana y la sociedad. Al mismo tiempo surge otra especie de relativismo: los individuos y las sociedades difieren profundamente $y$, por tanto, en igual medida varian también sus necesidades. No hay un omniabarcante 'bien para el hombre'. Hacer el diagnóstico de una situación particular y prescribir la mejor línea de conducta para una colectividad o un individuo, como hace el médico con su paciente, es, a los ojos de Protágoras, la tarea del sofista." "?

Eduardo García Máynez

INSTITUTO DE INVESTIGACIONES FiLOSÓficas

Universidad Nactonal Autónoma de MÉxico

73 Obra y tomo citados, p. 187 .

74 Ibid.

75 Ibid.

78 Aristóteles, Metaftsica, 1062 b, 15. Valentín García Yebra, edición trilingüe. Gredos,

S. A. Madrid, 1970 , p. 152.

77 Guthrie, obra y tomo citados en la nota 71, p. 187. 